\title{
ANALISIS POSTUR KERJA KARYAWAN PT.XYZ MENGGUNAKAN METODE OVAKO WORK POSTURE ANALYSIS SISTEM (Owas)
}

\author{
Mufrida Meri ${ }^{1}$, Rozza Linda ${ }^{2}$ dan Popi Gusti Rahayu ${ }^{3}$ \\ ${ }^{123}$ Teknik Industri Universitas Ekasakti, Jalan Veteran Dalam, Padang, Sumatera Barat, Indonesia, 25113 \\ Correspondence: mufridameri@gmail.com \\ Received: 120821 - Revised: 100921 - Accepted: 100921 - Published: 150921
}

\begin{abstract}
Abstrak. Tujuan dari penelitian ini adalah untuk menentukan kategori risiko sikap kerja karyawan pada PT.XYZ dengan menggunakan metode ovako work posture analysis system (OWAS). Berdasarkan hasil observasi awal terhadap sejumlah karyawan ternyata terdapat keluhan-keluhan yang dirasakan oleh pekerja pada anggota tubuh tertentu seperti leher, tulang punggung, pinggang, kaki dan bahu. Aktivitas kerja yang sering dilakukan oleh karyawan dilantai produksi PT.XYZ adalah gerakan membungkuk, jongkok, berdiri, selama satu hari kerja (8 jam) yang bisa menyebabkan keluhan musculoskeletal disorder (MSDs) yang merupakan penyakit atau gangguan pada jaringan lunak (otot, sendi, ligament, tendon, tulang rawan) dan sistem saraf. Adanya keluhan - keluhan yang dirasakan karyawan maka penelitian ini menggunakan metode ovako work posture analysis system (OWAS) yang merupakan metode untuk menilai pembebanan pada postur tubuh saat bekerja. Penerapan dari metode ini dapat memberikan suatu hasil yang baik, yang dapat meningkatkan kenyamanan kerja, sebagai peningkatan kualitas produksi, setelah dilakukannya perbaikan sikap kerja. Dari penelitian ini didapat hasil kategori risiko yang paling banyak adalah kategori risiko no.2 yaitu sikap kerja ini berbahaya pada sistem musculoskeletal disorder (sikap kerja mengakibatkan pengaruh ketegangan yang signifikan) perlu perbaikan segera mungkin.
\end{abstract}

Kata kunci: Musculoskeletal, risiko, OWAS, postur, karyawan

Citation Format: Meri. M.,, Linda. R., \& Rahayu. P.G.,. (2021). Analisis Postur Kerja Karyawan PT.XYZ Menggunakan Metode Ovako Work Posture Analysis Sistem (Owas). Prosiding Seminar Nasional Abdimas Ma Chung (SENAM), 2020, 86-93. 


\section{PENDAHULUAN}

PT. XYZ merupakan perusahaan yang bergerak di bidang produksi karet dan pengolahan karet mentah menjadi karet remah (crumb rubber). Dalam proses produksinya perusahaan ini telah menggunakan mesin dan peralatan pembantu seperti conveyor belt, mesin press, dan lain-lain. Namun dalam beberapa area masih cenderung mengandalkan tenaga manusia atau masih manual material handling untuk mengangkat, mendorong dan menimbang karet tersebut. Khususnya dibagian penimbangan yang dalam kegiatannya banyak melibatkan gerakan mengangkat. Kegiatan tersebut dilakukan berulang-ulang dan berisiko menimbulkan kecelakaan ataupun penyakit pada pekerja.

Berdasarkan observasi awal dan hasil wawancara yang telah dilakukan oleh peneliti pada 10 orang karyawan di PT. XYZ bahwa dari aktivitas yang dilakukan, karyawan mengalami keluhan musculoskeletal terutama keluhan rasa sakit pada bagian tubuh seperti punggung, lengan, kaki dan anggota tubuh lainnya. Sehingga penelitian ini menggunakan metode OWAS sebagai alat ukur untuk menganalisis postur kerja karyawan PT. XYZ. Menurut Tarwaka, 2015 metode ini merupakan sebuah metode yang sederhana dan dapat digunakan untuk menganalisa suatu pembebanan pada postur tubuh.

Penerapan dari metode ini dapat memberikan suatu hasil yang baik, yang dapat meningkatkan kenyamanan kerja, sebagai peningkatan kualitas produksi, setelah dilakukannya perbaikan sikap kerja. Sampai saat ini, metode ini telah ditetapkan secara luas diberbagai sektor industri. Dengan adanya penelitian ini diharapkan karyawan yang bekerja menggunakan manual material handling bisa terhindar dari keluhan musculoskeletal dan bisa memperbaiki sikap atau postur kerja.

\section{METODE PELAKSANAAN}

Aktivitas manual material handling yang melebihi batas kemampuan karyawan dapat menyebabkan kecelakaan kerja maupun penyakit berupa gangguan otot rangka / musculoskeletal disorders (MSDs). Untuk mengetahui kategori risiko dan tindakan perbaikan maka peneliti menggunakan metode ovako work posture analysis system (OWAS). Karyawan yang diteliti sebanyak 30 orang di lantai produksi PT. XYZ.

Menurut Tarwaka, 2015 prosedur OWAS dilakukan dengan melakukan observasi untuk mengambil data postur, beban/tenaga, dan fase kerja. Langkah selanjutnya adalah melakukan pengkodean berdasar data tersebut. Evaluasi penilaian didasarkan pada skor dari tingkat bahaya postur kerja yang ada. Kemudian dihubungkan dengan kategori tindakan 
yang harus diambil. Klasifikasi postur kerja dari metode OWAS adalah pada pergerakan tubuh bagian punggung ( a ack), lengan (arms), dan kaki (legs). Setiap postur tubuh tersebut terdiri dari 4 postur bagian belakang, 3 postur lengan, dan 7 postur kaki. Berat beban yang dikerjakan juga dilakukan penilaian mengandung skala 3 point.

\section{HASIL DAN PEMBAHASAN}

Pada metode OWAS, setelah dilakukan pengumpulan data dengan merekam aktivitas para pekerja setiap stasiun. Pengolahan data didapatkan berupa data postur kerja dengan menerjemahkan hasil rekaman. Kemudian diterjemahkan kedalam kode empat digit yang diperoleh dari pengelompokan tabel-tabel OWAS, dijelaskan pada contoh gambar dan tabel diberikut:

Proses Penimbangan

Karyawan

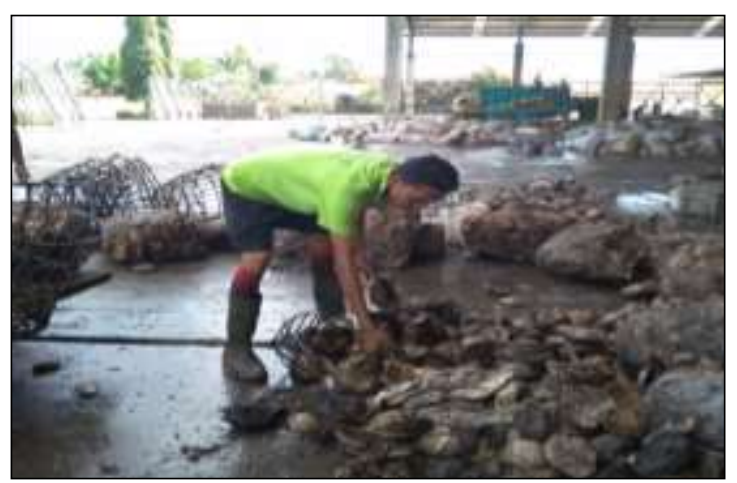

Gambar 1. Posisi Sikap Kerja Karyawan 1

Dari Posisi Sikap Kerja Karyawan 1 Pada Proses Penimbangan dapat diketahui:

Tabel 1. Kategori Tindakan Kerja OWAS Karyawan 1

\begin{tabular}{|c|c|c|c|c|c|c|c|c|c|c|c|c|c|c|c|c|c|c|c|c|c|c|c|}
\hline \multirow{2}{*}{ Back } & \multirow{2}{*}{ Arms } & \multicolumn{3}{|c|}{$\overline{1}$} & \multicolumn{3}{|c|}{2} & \multicolumn{3}{|c|}{3} & \multicolumn{3}{|c|}{4} & \multicolumn{3}{|c|}{5} & \multicolumn{3}{|c|}{$\overline{6}$} & \multicolumn{3}{|c|}{7} & \multirow{2}{*}{$\begin{array}{l}\text { Legs } \\
\text { Load } \\
\end{array}$} \\
\hline & & $\mathbf{1}$ & 2 & 3 & 1 & 2 & 3 & $\mathbf{1}$ & 2 & 3 & 1 & 2 & 3 & 1 & 2 & 3 & $\mathbf{1}$ & 2 & 3 & $\mathbf{1}$ & 2 & 3 & \\
\hline \multirow{3}{*}{$\mathbf{1}$} & 1 & 1 & 1 & 1 & 1 & 1 & 1 & 1 & 1 & 1 & 2 & 2 & 2 & 2 & 2 & 2 & 1 & 1 & 1 & 1 & 1 & 1 & \multirow{12}{*}{$x$} \\
\hline & 2 & 1 & 1 & 1 & 1 & 1 & 1 & 1 & 1 & 1 & 2 & 2 & 2 & 2 & 2 & 2 & 1 & 1 & 1 & 1 & 1 & 1 & \\
\hline & 3 & 1 & 1 & 1 & 1 & 1 & 1 & 1 & 1 & 1 & 2 & 2 & 2 & 2 & 2 & 2 & 1 & 1 & 1 & 1 & 1 & 1 & \\
\hline \multirow{3}{*}{2} & 1 & 2 & 2 & 3 & 2 & 2 & 3 & 2 & 2 & 3 & 3 & 3 & 3 & 3 & 3 & 3 & 2 & 2 & 2 & 2 & 2 & 3 & \\
\hline & 2 & 2 & 2 & 3 & 2 & 2 & 3 & 2 & 3 & 3 & 3 & 4 & 4 & 3 & 4 & 4 & 3 & 3 & 4 & 2 & 3 & 4 & \\
\hline & 3 & 3 & 3 & 4 & 2 & 2 & 3 & 3 & 3 & 3 & 3 & 4 & 4 & 4 & 4 & 4 & 4 & 4 & 4 & 2 & 3 & 4 & \\
\hline \multirow{3}{*}{3} & 1 & 1 & 1 & 1 & 1 & 1 & 1 & 1 & 1 & 2 & 3 & 3 & 3 & 4 & 4 & 4 & 1 & 1 & 1 & 1 & 1 & 1 & \\
\hline & 2 & 2 & 2 & 3 & 1 & 1 & 1 & 1 & 1 & 2 & 4 & 4 & 4 & 4 & 4 & 4 & 3 & 3 & 3 & 1 & 1 & 1 & \\
\hline & 3 & 2 & 2 & 3 & 1 & 1 & 1 & 2 & 3 & 3 & 4 & 4 & 4 & 4 & 4 & 4 & 4 & 4 & 4 & 1 & 1 & 1 & \\
\hline \multirow{3}{*}{4} & $\mathbf{1}$ & 2 & 3 & 3 & 2 & 2 & 3 & 2 & 2 & 3 & 4 & 4 & 4 & 4 & 4 & 4 & 4 & 4 & 4 & 2 & 3 & 4 & \\
\hline & 2 & 3 & 3 & 4 & 2 & 3 & 4 & 3 & 3 & 3 & 4 & 4 & 4 & 4 & 4 & 4 & 4 & 4 & 4 & 2 & 3 & 4 & \\
\hline & 3 & 4 & 4 & 4 & 2 & 3 & 4 & 3 & 3 & 4 & 4 & 4 & 4 & 4 & 4 & 4 & 4 & 4 & 4 & 2 & 3 & 4 & \\
\hline
\end{tabular}

Tabel 2. Kategori Sikap Kerja Karyawan 1 


\begin{tabular}{|c|l|}
\hline Nilai Kategori & \multicolumn{1}{|c|}{ Aksi Kategori } \\
\hline 1 & Tidak perlu perbaiakan \\
\hline 2 & Perlu perbaikan dimasa yang akan datang \\
\hline 3 & Perlu perbaikan segera mungkin \\
\hline 4 & Perlu perbaikan secara langsung/saat ini \\
\hline
\end{tabular}

- Kode sikap punggung: 2 Bungkuk ke depan

- Kode sikap Lengan: 1 Kedua lengan berada di bawah bahu

- Kode sikap Kaki: 4 Berdiri atau jongkok dengan kedua lutut

- Kode berat beban: 1 Berat beban $<10 \mathrm{Kg}$

Jadi postur kerja pada karyawan 1 yaitu postur kerja dengan kode 2141, yang merupakan postur kerja dengan kategori tindakan perbaikan level 3, pada sikap ini berbahaya bagi sistem musculoskeletal (sikap kerja mengakibatkan pengaruh ketegangan yang sangat signifikan). Perlu perbaikan sesegera mungkin.

Tabel 3. Rekapitulasi hasil pengolahan data OWAS 


\begin{tabular}{|c|c|c|c|c|}
\hline No & Karyawan & Kode OWAS & Nilai Kategori & Aksi Kategori \\
\hline 1 & Karyawan 1 & 2141 & 3 & Perlu perbaikan segera mungkin \\
\hline 2 & Karyawan 2 & 2131 & 2 & Perlu perbaikan dimasa yang akan datang \\
\hline 3 & Karyawan 3 & 4141 & 4 & Perlu perbaikan secara langsung/saat ini \\
\hline 4 & Karyawan 4 & 2141 & 3 & Perlu perbaikan segera mungkin \\
\hline 5 & Karyawan 5 & 4141 & 4 & Perlu perbaikan secara langsung/saat ini \\
\hline 6 & Karyawan 6 & 1131 & 1 & Tidak perlu perbaiakan \\
\hline 7 & Karyawan 7 & 1141 & 2 & Perlu perbaikan dimasa yang akan datang \\
\hline 8 & Karyawan 8 & 2133 & 3 & Perlu perbaikan segera mungkin \\
\hline 9 & Karyawan 9 & 1233 & 1 & Tidak perlu perbaiakan \\
\hline 10 & Karyawan 10 & 4143 & 4 & Perlu perbaikan secara langsung/saat ini \\
\hline 11 & Karyawan 11 & 2143 & 3 & Perlu perbaikan segera mungkin \\
\hline 12 & Karyawan 12 & 2123 & 3 & Perlu perbaikan segera mungkin \\
\hline 13 & Karyawan 13 & 2123 & 3 & Perlu perbaikan segera mungkin \\
\hline 14 & Karyawan 14 & 2111 & 2 & Perlu perbaikan dimasa yang akan datang \\
\hline 15 & Karyawan 15 & 2111 & 2 & Perlu perbaikan dimasa yang akan datang \\
\hline 16 & Karyawan 16 & 3111 & 1 & Tidak perlu perbaiakan \\
\hline 17 & Karyawan 17 & 1111 & 1 & Tidak perlu perbaiakan \\
\hline 18 & Karyawan 18 & 2111 & 2 & Perlu perbaikan dimasa yang akan datang \\
\hline 19 & Karyawan 19 & 3111 & 1 & Tidak perlu perbaiakan \\
\hline 20 & Karyawan 20 & 3111 & 1 & Tidak perlu perbaiakan \\
\hline 21 & Karyawan 21 & 4142 & 4 & Perlu perbaikan secara langsung/saat ini \\
\hline 22 & Karyawan 22 & 2131 & 2 & Perlu perbaikan dimasa yang akan datang \\
\hline 23 & Karyawan 23 & 2152 & 3 & Perlu perbaikan segera mungkin \\
\hline 24 & Karyawan 24 & 3132 & 1 & Tidak perlu perbaiakan \\
\hline 25 & Karyawan 25 & 2132 & 2 & Perlu perbaikan dimasa yang akan datang \\
\hline 26 & Karyawan 26 & 2132 & 2 & Perlu perbaikan dimasa yang akan datang \\
\hline 27 & Karyawan 27 & 4122 & 2 & Perlu perbaikan dimasa yang akan datang \\
\hline 28 & Karyawan 28 & 2132 & 2 & Perlu perbaikan dimasa yang akan datang \\
\hline 29 & Karyawan 29 & 2132 & 2 & Perlu perbaikan dimasa yang akan datang \\
\hline 30 & Karyawan 30 & 1132 & 1 & Tidak perlu perbaiakan \\
\hline
\end{tabular}

\section{Pembahasan}

\section{Analisis Postur Kerja Karyawan Pada Proses Penimbangan}

a. Karyawan yang berada pada kategori 1 sebanyak 2 orang karyawan, yaitu karyawan 6 dan 9, (pada sikap ini tidak masalah pada sistem musculoskeletal, tidak perlu perbaikan). Adapun foto postur kerja karyawan 6 dan 9 ini dapat dilihat pada gambar 2 berikut ini: 


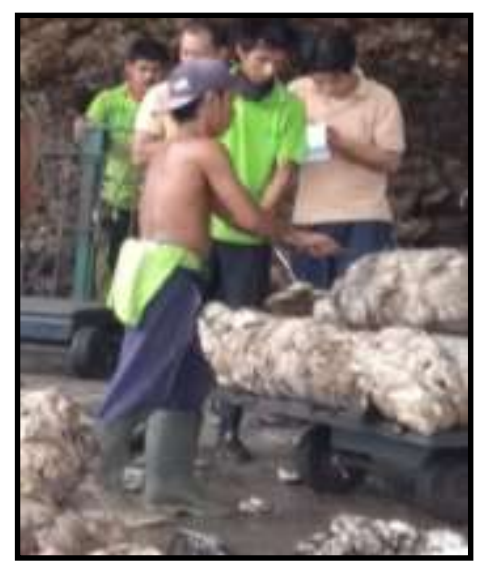

a

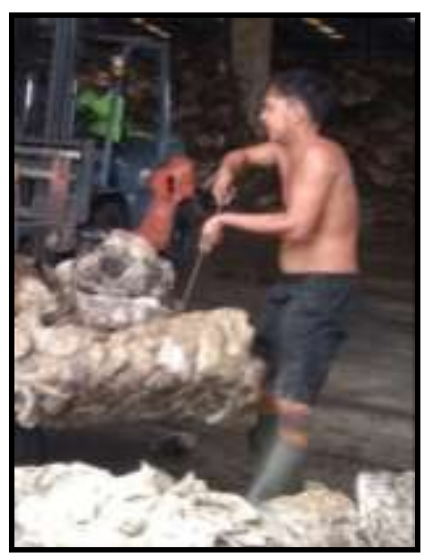

b

Gambar 2. postur kerja karyawan 6 dan 9

b. Kategori 2 sebanyak 2 orang karyawan, yaitu karyawan 2 dan 7, (pada sikap ini berbahaya pada sistem musculoskeletal, perlu perbaikan dimasa yang akan datang). Adapun foto postur kerja karyawan 2 dan 7 ini dapat dilihat pada gambar 3 berikut ini:

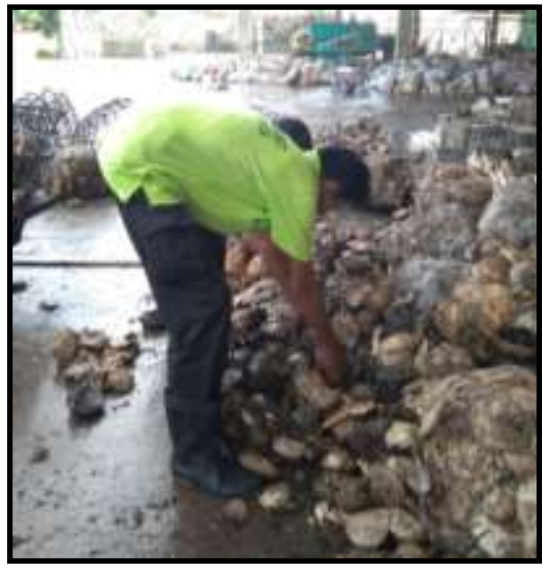

a

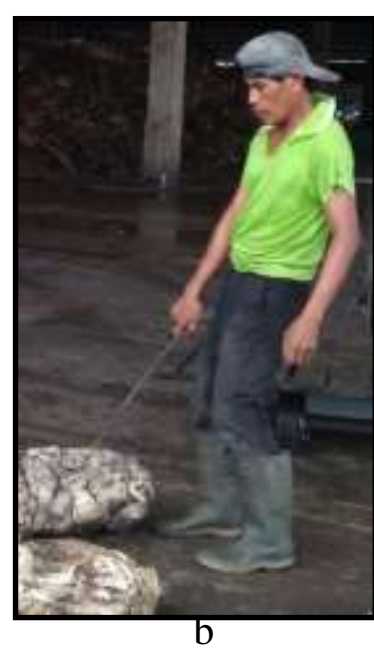

Gambar 3. Postur kerja karyawan 2 dan 7

c. Kategori 3 sebanyak 6 orang karyawan, yaitu karyawan 1, 4, 8, 11, 12, dan 13, pada sikap ini berbahaya pada sistem musculoskeletal. Perlu perbaikan sesegera mungkin. Adapun foto postur kerja karyawan di atas dapat dilihat pada gambar 4 berikut ini: 


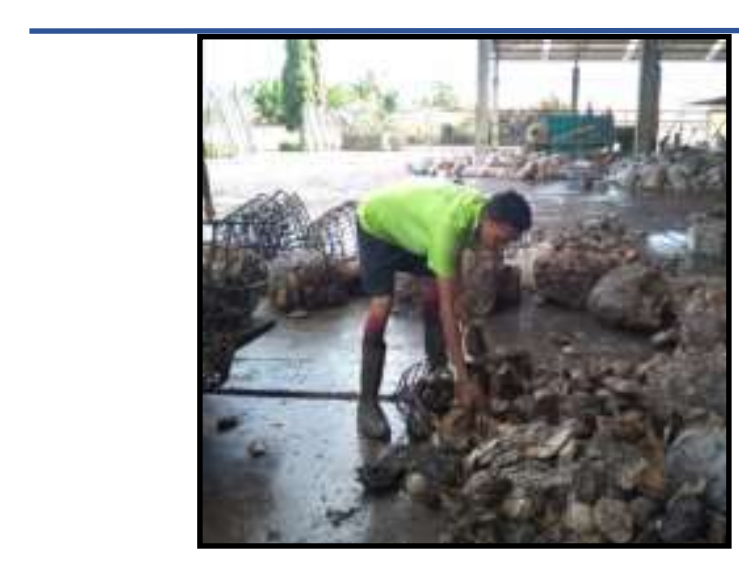

a

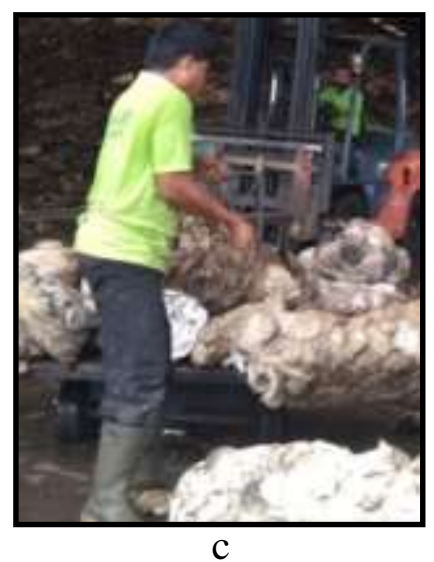

b

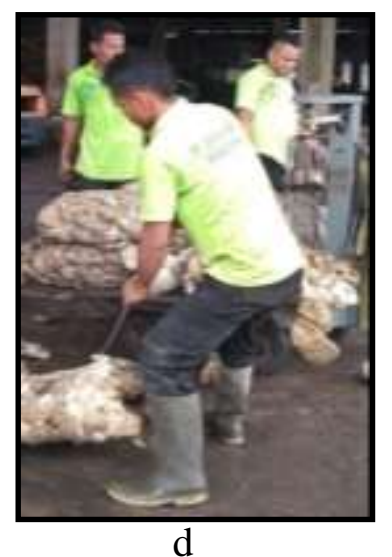

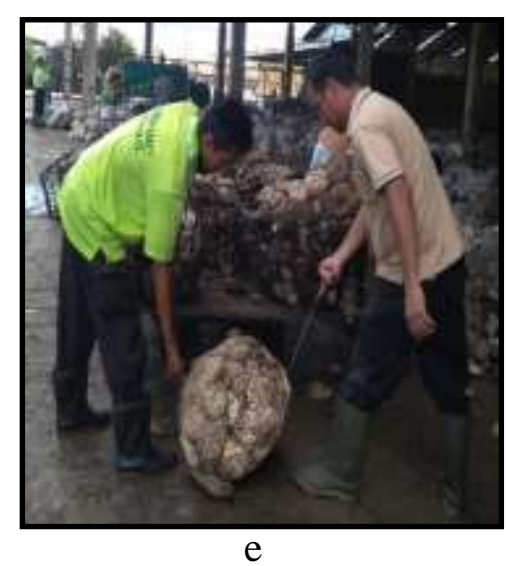

Gambar 4. Foto postur kerja karyawan

d. Kategori 4 sebanyak 3 orang karyawan, yaitu karyawan 3, 5 dan 10, pada sikap ini berbahaya pada sistem musculoskeletal. Perlu perbaikan secara langsung/saat ini.

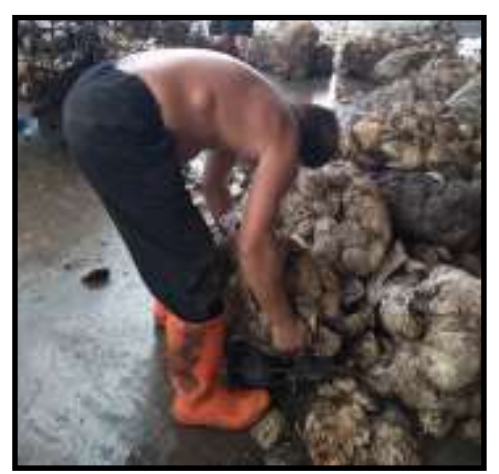

a

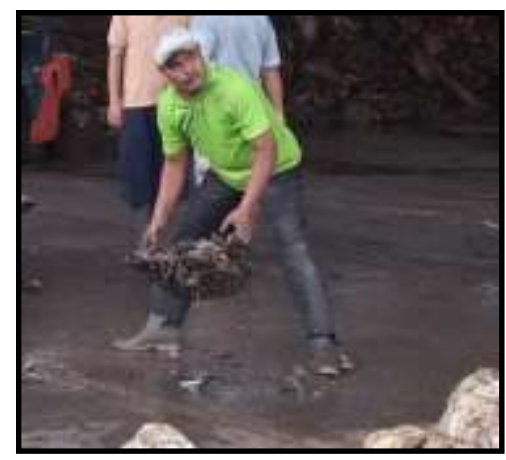

b

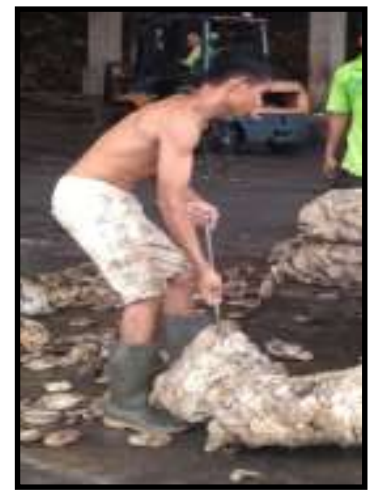

c

Gambar 5. Foto Postur kerja Karyawan 3, 5, 10

\section{KESIMPULAN}

Dari hasil perhitungan nilai OWAS terhadap 30 orang karyawan, postur kerja teridentifikasi kedalam beberapa karegori bahaya. Kategori 1 sebanyak 8 orang karyawan, pada sikap ini 
tidak masalah pada sistem musculoskeletal. Tidak perlu perbaikan. Kategori 2 sebanyak 11 orang karyawan, pada sikap ini berbahaya pada sistem musculoskeletal (sikap kerja mengakibatkan pengaruh ketegangan yang signifikan). Perlu perbaikan dimasa yang akan datang. Kategori 3 sebanyak 7 orang karyawan, pada sikap ini berbahaya pada sistem musculoskeletal (sikap kerja mengakibatkan pengaruh ketegangan yang sangat signifikan. Perlu perbaikan sesegera mungkin). Dan kategori 4 sebanyak 4 orang karyawan, pada sikap ini berbahaya pada sistem musculoskeletal (sikap kerja ini mengakibatkan risiko yang jelas). Perlu perbaikan secara langsung/saat ini.

\section{UCAPAN TERIMA KASIH}

Ucapan terimakasih dan penghargaan yang tak terhingga kepada Allah SWT dan Prodi Teknik Industri Universitas Ekasakti serta teman- teman dosen di Teknik industri Universitas Ekasakti Padang Sumatera Barat.

\section{DAFTAR PUSTAKA}

Meri, Z 2019, 'Analisis postur kerja karyawan dibagian pengangkatan bahan baku dengan metode OWAS dan RULA di PT. Sumatera Tropical Spices', Majalalah Ilmiah UPI YPTK, vol. 26, no. 2, hh.35-44.

Nurmianto, E 2003, Ergonomi: konsep dasar dan aplikasinya edisi pertama, Surabaya, Guna widya.

Sedarmayanti, 2011, Tata kerja dan produktivitas kerja, Mandar Maju, Bandung.

Sutalaksana, Z 2006, Teknik perancangan sistem kerja, ITB Bandung.

Tarwaka, 2015, Ergonomi industri: dasar-dasar pengetahuan ergonomi dan aplikasi di tempat kerja, Surakarta, Harapan Press.

Wignjosoebroto, Sritomo 2006, Ergonomi, studi gerak dan waktu, GunaWidya, Surabaya. 